\section{A giant mandibular dentigerous cyst associated with a compound odontoma: A case report}

\section{Mandibulada kompound odontoma ile ilișkili dev bir dentigeröz kist: Bir olgu sunumu}

\author{
Assist. Prof. Sercan Küçükkurt \\ Istanbul Aydın University, Faculty of Dentistry, \\ Department of Oral and Maxillofacial Surgery, \\ Istanbul \\ Dr. Hüseyin Can Tükel \\ Çukurova University, Faculty of Dentistry, \\ Department of Oral and Maxillofacial Surgery, Adana
}

Assoc. Prof. Emre Barıs

Gazi University, Faculty of Dentistry, Department of Oral Pathology, Ankara

Received: 27 July 2017

Accepted: 09 November 2017

doi: 10.5505/yeditepe.2018.62533

\section{Corresponding author:}

Assist. Prof. Sercan Küçükkurt

İstanbul Aydın Üniversitesi, Diş Hekimliği Fakültesi

Beşyol Mh. Akasya Sk. No:6 Sefaköy Küçükçekmece 34100 İstanbul - Türkiye

Phone: 905326205590

E-mail: skucukkurt@gmail.com

\section{SUMMARY}

Odontoma is a non-aggressive ectomesenchymal tumor of unknown origin that are more considered developmental malformations (hamartomas) than benign neoplasms. Dentigerous cyst is an epithelium-lined sac enclosing the crown of an unerupted tooth. Occasionally, the dentigerous cyst is associated with odontoma. Dentigerous cysts that have not been noticed for a long time can reach huge sizes due to effect of their asymptomatic structure. A 53-year-old male referred to our department with swelling on his right mandibular region. Clinical and radiographic examination revealed an extensive radiolucency extending from left second premolar to right angle of mandibula. Previously marsupialization of the cyst was tried from two different location. However, as a result of the failure of the process the patient was referred to our department. Enucleation of the cyst with odontoma was done under local anesthesia with sedation. Also associated teeth were extracted which have periodontal problems and mobility. At the 2 years of follow up, there was a complete healing in cyst region and no recurrence. Histopathological examination revealed a dentigerous cyst associated with an odontoma that is because there was no any other unerupted tooth. The association of a huge dentigerous cyst with a compound odontoma makes this case rare and interesting.

Keywords: Dentigerous cyst, odontoma, mandible

\section{ÖZET}

Odontoma, benign neoplazmadan daha çok gelişimsel malformasyon (hamartom) olarak kabul edilen agresif olmayan ektomezenkimal bir tümör çeşididir. Dentigeröz kistler, sürmemiş bir diş kronuna eşlik eden iyi huylu odontojen kaynaklı kistlerdir. Dentigeröz kistlerin nadiren de odontoma ile ilișkili olduğu bilinmektedir. Dentigeröz kistler uzun süre fark edilmezlerse, asemptomatik yapılarının etkisiyle büyük boyutlara ulaşabilirler. 53 yaşındaki bir erkek hasta sağ mandibular bölgede şişlik ile kliniğimize başvurdu. Klinik ve radyografik incelemelerde, sol ikinci premolar dişten mandibulanın sağ angulus bölgesine uzanan geniş bir radyolusent alan saptandı. Daha önce kistin tedavisi amacıyla iki farklı noktadan marsupyalizasyon işleminin denendiği ancak işlemin radyolusent sahada herhangi bir küçülme ya da iyileşmeye sebep olmadığına karar verilmesinin ardından hasta tarafımıza yönlendirildiği öğrenildi. Odontoma ile kistin enükleasyonu lokal anestezi ile derin sedasyon yardımıyla yapıldı. Ayrıca bölgedeki periodontal sorunlar ve mobilite gösteren dişler hastanın ilgili dişlere önerilen tedavi seçeneklerini reddetmesi üzerine çekildi. 2 yıllık takipte, kist bölgesindeki tam bir iyileşme gözlendi, nüks belirtisine rastlanmadı. Histopatolojik tanı, bölgede sürmemiş başka bir dişin de var olmamasına dayanarak odontoma ile ilişkili dentigeröz kist olarak konuldu. Bu vakada nadir görülen, kompound odontoma ile ilişkili dev boyutta dentigeröz kist olgusu rapor edilmektedir.

Anahtar kelimeler: Dentigeröz kist, odontoma, mandibula 


\section{INTRODUCTION}

Dentigerous cyst is an odontogenic cyst that develops around crown of an impacted tooth. It is usually seen around the mandibular third molar teeth of young patients. Lesions are usually asymptomatic unless they are associated with infection and usually diagnosed on routine radiographs. The dentigerous cyst can be rarely seen associated with odontomas. It is estimated that $27 \%$ of cases related to an odontoma., ${ }^{1,2}$ In 1867 Paul Broca described odontoma as a non-aggressive benign ectomesenchymal tumor of unknown origin. Odontomas may be associated with the presence of impacted teeth, trauma, genetic factors, local infections and dentigerous cysts. ${ }^{1,3}$ Preliminary diagnosis of both lesions is done by the main imaging methods and then confirmed by histopathological analysis. Failure to diagnose or treat, especially after the cyst has reached enormous dimensions, can cause pathologic bone fractures and resection of the jawbone. These can lead to variable problems, from aesthetic and phonetic to severe malocclusions. ${ }^{1,2}$ For this reason, early and accurate diagnosis of cyst and its cause is of great importance. Treatment of odontoma is surgical excision and this treatment is very successful, recurrence is rarely seen, and bone repair is done smoothly in the area. ${ }^{4}$ The treatment for dentigerous cysts is surgical excision with removal of related teeth in similar manner, and in some cases it may be necessary to marsupialize the lesion for reduction of bone defect size prior to surgical intervention. ${ }^{2,5,6}$

In this case report, a huge dentigerous cyst, which occupying $2 / 3$ of the mandibular corpus, accompanied by a compound odontoma, was diagnosed in a 56-year-old male patient by implementing cone beam computed tomography (CBCT) and treated, histologically examined and followed-up for 2 years.

\section{CASE REPORT}

A 56-year-old male referred to our department with an unable to treated lesion in his right mandibular region. Clinical and radiographic examination revealed an extensive radiolucency extending from left second premolar to right angle of mandible. Previously marsupialization of the cyst was tried by another clinician from two different space. However, at the end of the 8-month period, the procedure did not provide any contribution to shrinkage of cyst and then the patient was referred to our department.

Clinical examination revealed that the patient did not have any pain in the region under the current conditions. In the right mandibular molar region, there was an expansion in the bone that shaded the vestibule sulcus and two opened intra-lesion window entities for the previous marsupialization process, one from molar region, and one at the level of the incisor teeth. Nearly all of the teeth in the region, which are still in the mouth as complete as the third molar, have class 2 mobility according to Miller classification. In the cyst region there is a third molar with caries and severe tissue loss. The patient has poor oral hygiene, but no serious caries was found in the other teeth associated with the cyst. Patient has also mild paresthesia in the region (Figure 1).

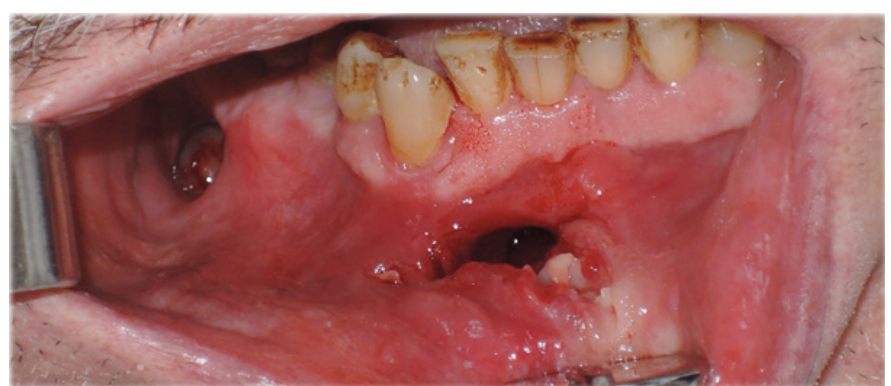

Figure 1. Preoperative intraoral image showing the previous surgical marsupialized windows

Orthopantomography image revealed a multilobular radiolucent lesion with a straight border extending from the right mandibular angulus region to the left second premolar tooth level, completely covering the mandibular basis and the alveolar crest in the vertical direction. There is a radiopaque appearance between the apices of the right mandibular canine and the premolar teeth, in the mental foramen region, resembling a tooth crown without root. In the molar region due to the pressure of the lesion, the mandibular nerve is displaced to the lower border of the mandible (Figure 2).

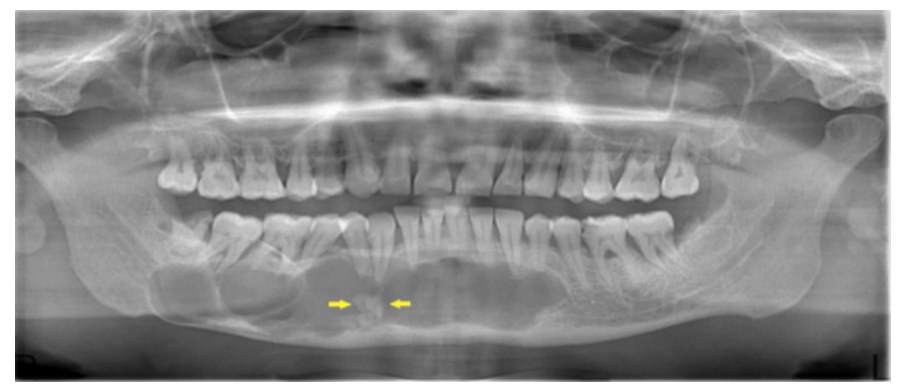

Figure 2. Orthopantomography image showing radiolucent cystic lesion and a radiopaque formation at the apex of the canine

It has been decided to obtain a CBCT from the region in order to evaluate its content, its borders and the relation of the lesion with surrounding anatomical formations. On the CBCT image, bone expansion was detected in the buccolingual region of the cyst. Especially in the molar region, the lesion makes a significant expansion and shows extrabony placement in the buccal region. However, it is also thought that this situation may eventually result of the previous marsupialization process which has been going on for about 8 months. The lesions did not cause perforation in the bone except the marsupialization regions. The mandibular canal is located in the basal base of mandible due to the compression of the cyst. Compound odontoma was initially diagnosed after СBCT examination for the formation of a single piece amorphous structure located in the apex of the canine surrounded by a radiolucent 
area, which resembles a non-root tooth crown in the size of 7-8 $\mathrm{mm}$ and in contact with only the basal base of mandible (Figure 3-4).

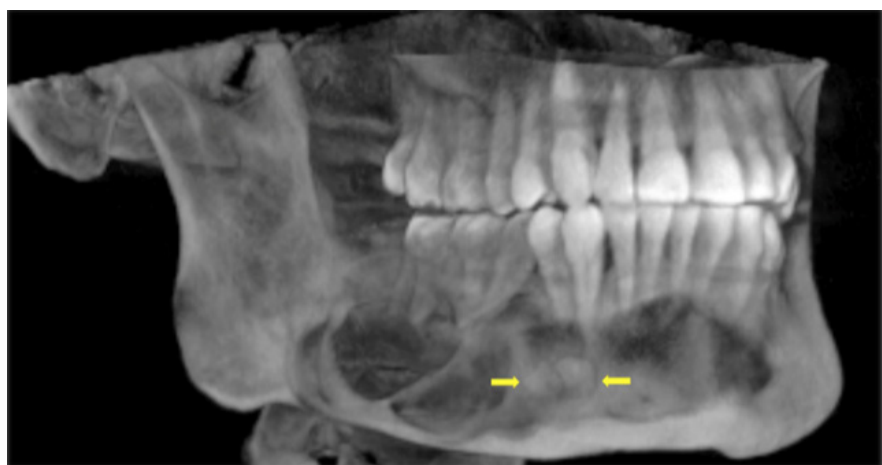

Figure 3. СВCT image (3D) showing multilobular structure of the cyst and a radiopaque area surrounded by thin radiolucent border

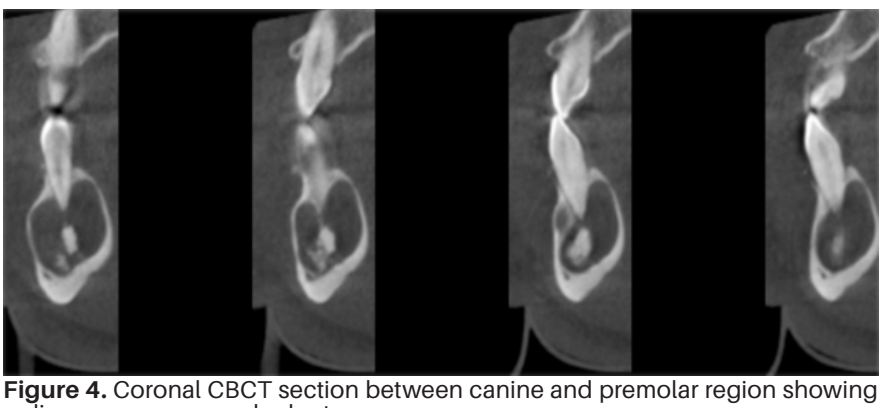
radiopaque compound odontoma

During the interviews with the patient, although detailed information was given about the benefits of the retrying marsupialization procedure and the risks of the enucleation process, the patient refused marsupialization and demanded enucleation of the cyst immediately because of the long duration of the previous procedure that resulted with failure.

Enucleation of the cyst with odontoma was done under local anesthesia with sedation. Also associated teeth were extracted which have also pericoronal bone loss and severe mobility (Figure 5).

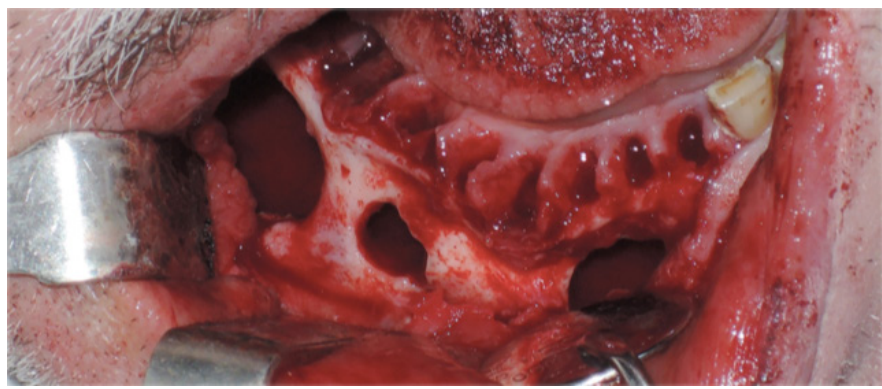

Figure 5. Intraoperative image after enucleation of the cyst and extraction of the

Primary wound closure was achieved by periosteal releasing incisions. Histopathological examination by sampling from four different regions confirmed initial dentigerous cyst diagnosis (Figure 6). At the 2 years follow up, there was a complete healing in cyst region and no evidence of recurrence (Figure 7). Paresthesia was also disappeared.

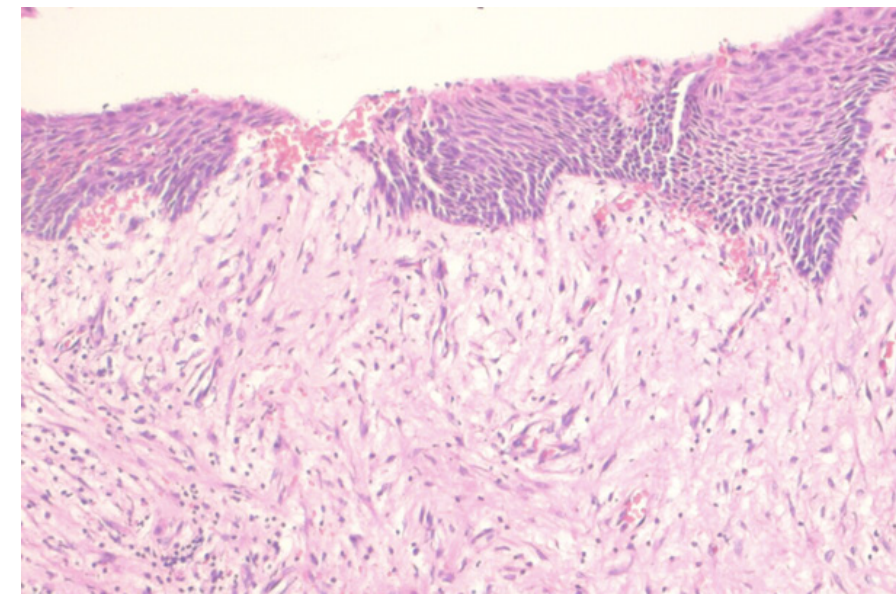

Figure 6. Dentigerous cyst with a few rows of non-keratinized odontogenic epithelium (H\&E 200x)

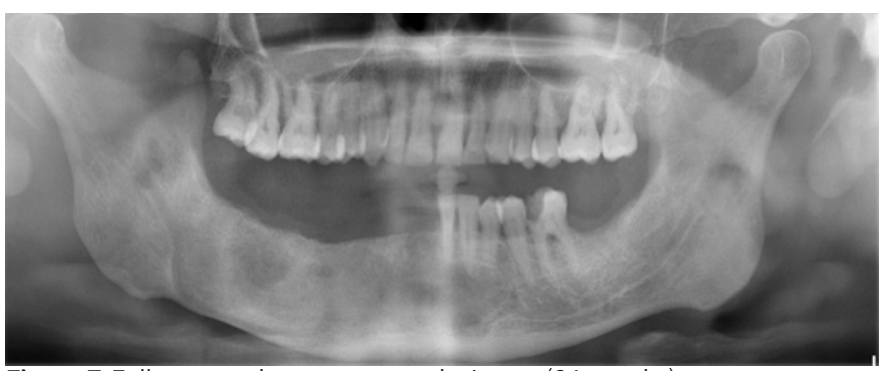

Figure 7. Follow-up orthopantomography image (24 months)

\section{DISCUSSION}

The dentigerous cyst can be seen around the impacted teeth and more rarely associated with odontomas. Radiographically, the dentigerous cyst is composed of a smooth and distinctly limited sclerotic radiolucent area around an impacted tooth. Upon reaching a diameter of $2 \mathrm{~cm}$, sensitivity depending on pressure on peripheral anatomical structure, bone expansion, displacement in teeth may accompany the cyst. Histologically, it is thought that the epithelial component of the enamel organ develops with cystic degeneration and fluid accumulation between the reduced enamel epithelium and dental mines. The cyst is developed by the cystic degeneration of the epithelial component of the enamel organ and by the accumulation of fluid between the reduced enamel epithelium and enamel. Histopathologically, the cyst is surrounded by fibrous conjunctival tissue capsule and two to four layers of flattened epithelial lining of cells. The keratinization of the epithelial layer can be seen, but not always. Complications associated with dentigerous cysts includes; Pathological bone fracture, loss of permanent teeth, bone deformities and the development of malignancies such as ameloblastoma, squamous cell carcinoma and intraosseous mucoepidermoid carcinoma. ${ }^{1,25,7,8}$ In this case, the patient had to lose all the teeth in the region due to asymptomatically enlaged cyst and was not noticed for a long time. In our opinion, it can be considered a great chance for the patient not to have a trauma to the region in the presence of this cyst, which can cause jaw fracture very easily. Odontomas are among the most common odontogenic tumors of jaw bones and constitute approximately $22 \%$ of odon- 
togenic tumors. ${ }^{6}$ Despite odontoma has been reported in almost all age groups, the majority of cases (84\%) occur under 30 years of age, most frequently during the second decade of life and less than $10 \%$ in patients over 40 years of age. ${ }^{9}$ The incidence of odontomas according to gender does not differ. Odontomas are more common in the permanent dentition than in the primary dentition. Microscopically, odontomas consist of enamel, dentin, cement and pulp tissue in varying amounts. Odontomas are considered developmental malformations (hamartoma) more than benign neoplasms. ${ }^{13,5,10}$

It is thought that odontoma is caused by budding of extraodontogenic epithelial cells from dental lamina. This cell cluster forms a large mass of dental tissue that can settle in an abnormal configuration but consists of normal enamel, dentin, cementum and pulp ${ }^{1}$. Hitchin ${ }^{11}$ suggests that odontomas interact with a mutant gene or interference, possibly with genetic control of tooth development after birth. Odontoma originate from enamel producing odontogenic epithelium and the odontogenic mesenchyme, which produces dentin by odontoblast differentiation. Since it is composed of products of both cell types, it was previously called composite odontomas.

The World Health Organization has classified odontomas in two subgroups as compound and complex according to morphological differentiation. The compound odontoma is composed of small dental structures, while the complex type is composed of enamel and dentin conglomerate masses which do not bear anatomical resemblance to the dentition. ${ }^{1,3}$ Both types can grow to an average size of about $6 \mathrm{~cm}$ and often their growth stop when they reach these dimensions. ' Clinically, they are classified as intraosseous (central), peripheral (soft tissue or extra-osseous), and eruption odontomas. Intraosseous odontomas often occur as compound odontoma in the anterior maxilla, complex odontoma in the mandibular molar region, and have a rate of about $51 \%$ in all odontomas. Peripheral odontomas are less common and occur in the soft tissue on the alveolar crest region and are usually seen as a compound type. Eruption odontoma occurs around the crown of an erupting or impacted tooth, or appear superficially on the bone surface. ${ }^{9,12}$ According to radiographic examination of the patient, intraosseous compound odontoma was diagnosed in this case. Compound odontoma is defined as a lesion that is caused by extreme proliferation of dental lamina and which regularly displays all dental lamina tissues and is often seen in dental lamina form. Compound type consists of dental-like structures or denticles arranged on a fibrous stroma. Compound odontomas are more common in 1:2 ratio than complex odontomas and are usually diagnosed in the maxilla anterior region during the second and third decades of life'. However, compound odontoma follicles are rarely invol- ved in cyst development and cysts. The complex type affects young adults alike, but is more common in the posterior region of the mandible. The morphologically irregular structure consists of dentin, cement and enamel structures. ${ }^{1,3,5,9}$

Radiographically compound odontoma is seen as a cluster of dental-like structures surrounded by a radiolucent area with variable dimensions and shapes. Complex odontoma can be seen radiographically as irregularly bordered uniform radiopacity surrounded by a radiolucent area in the form of amorphous calcification dental tissue masses and can be confused with osteoma or some highly calcified bone lesions. In most cases the lesions are asymptomatic but may cause thickening of the cortical bone layer. It is noticed when routine radiographic examinations are being explored or investigated the reason for a not erupted tooth. ${ }^{1,3,5,9,13}$

Cystic involvement of compound odontoma is very rare. The majority of reported cystic odontoma cases to date are the cases of complex odontoma. As far as we know, only five cystic compound odontoma cases have been reported. The type of cyst that develops around the compound odontoma follicle is difficult to predict in the early stages of development. 6 Microscopically, cystic odontomas are characterized by the presence of a dental follicle-like layered squamous epithelium associated with an odontoma. They are surrounded by a connective tissue capsule containing chronic inflammatory cell infiltration and odontogenic epithelial islets. ${ }^{5}$

Diagnosis is based on radiological features and histopathologic analysis of the lesions. Radiographically, the cystic compound odontoma is rarely confused with other lesions. However, when the lesion is in a mixed radiopaque-radiolucent stage, it can be confused with other lesions of jaws with similar location, age incidence and radiographic properties. In some cases, the radiological appearance may resemble fibrosis lesions. Ameloblastic fibroodontoma can closely mimic the appearance of the odontomas. Odontomas may also give a cementoblastoma appearance if radiographically superpose on the roots. In addition, complex odontomas radiologically resemble osteoblastomas, ossifying fibroma and even osteomas. ${ }^{1,3,14,15}$

In our case, ameloblastic fibro-odontoma, calcific odontogenic cyst, pindborg tumor and calcifying odontogenic cyst were considered at the first encounter with clinical and radiological examination. After correlation between clinical and radiographic findings, in conventional radiography supernumerary tooth, compound odontoma on СВCT and intraoperative surgical observation and final diagnosis of compound odontoma accompanied by dentigerous cyst was made histopathologically. Histopathological analysis of the case reported that cystic lesion with 
a row of non-keratinized odontogenic epithelium accompanied by compound odontoma.

Recently, many reports have emphasized the benefits and features of CT scans in identifying these types of lesions. СBCT may be more useful to confirm the presence of calcifications on the cyst wall than conventional radiography. This may not be detected by simple radiographs because of the overlapping of anatomical structures. CBCT has a wide range of applications and it is very useful for determining the size and condition of the internal structure of the lesions, root fractures, determination of the position of impacted tooth and relation with the surrounding anatomical structures, and also pathological conditions in the jaw bones. In addition, during the diagnostic process, the three-dimensional image of the cysts and the imaging of the tumors of the maxillofacial region may provide vital information for planning the treatment plan. ${ }^{16-18}$

In the present case, conventional radiographs could not provide useful information for accurate diagnosis of the lesion because superimposed images revealed a unilocular radiopaque image with a structure resembling a small tooth. This led to the thought of a supernumerary tooth entity in the region. Thus, we emphasize that the CBCT image makes it possible to investigate a three-dimensional visualization of the lesion, as well as showing the relationship between the cystic structure and the odontoma in it, because the cyst has a multilobular appearance due to ongoing resorption of trabecular bone structures in the cystic cavity, odontoma was indistinguishable. Conventional radiography has identified a cystic lesion in the region of the image, but a CBCT was needed to elucidate the lesion borders and internal structure. It was possible to define the presence of odontoma within the cystic lesion and to plan the treatment properly, but only after the use of $\mathrm{CBCT}$ images. СВCT proved once again how effective it is to diagnose jaw neoplasms. For this reason, in our case, the details of the radiographic pattern and the internal structures and odontoma displayed with СВCT images served as an important tool in achieving a satisfactory diagnosis and treatment.

\section{REFERENCES}

1. Astekar M, Manjunatha BS, Kaur P, Singh J. Histopathological insight of complex odontoma associated with a dentigerous cyst. BMJ Case Rep 2014; 2014.

2. Wanjari SP, Tekade SA, Parwani RN, Managutti SA. Dentigerous cyst associated with multiple complex composite odontomas. Contemp Clin Dent 2011; 2: 215-217.

3. Soluk Tekkesin M, Pehlivan S, Olgac V, Aksakalli N, Alatli C. Clinical and histopathological investigation of odontomas: review of the literature and presentation of $160 \mathrm{ca}$ ses. J Oral Maxillofac Surg 2012; 70: 1358-1361.

4. Serra-Serra G, Berini-Aytes L, Gay-Escoda C. Erupted odontomas: a report of three cases and review of the lite- rature. Med Oral Patol Oral Cir Bucal 2009; 14: E299-303. 5. Costa V, Caris AR, Leon JE, Ramos CJ, Jardini V, Kaminagakura E. Cystic Odontoma in a Patient with Hodgkin's Lymphoma. Case Rep Dent 2015; 2015: 292819.

6. Kalaskar RR, Kalaskar AR, Pol CA, Ghige SK. Cystic compound odontome in the anterior maxilla: A rare case report. Indian J Oral Sci 2012; 3: 168-171.

7. Ikeshima A, Tamura Y. Differential diagnosis between dentigerous cyst and benign tumor with an embedded tooth. J Oral Sci 2002; 44: 13-17.

8. Moosvi Z, Tayaar SA, Kumar GS. Neoplastic potential of odontogenic cysts. Contemp Clin Dent 2011; 2: 106-109.

9. Arunkumar KV, Vijaykumar, Garg N. Surgical management of an erupted complex odontoma occupying maxillary sinus. Ann Maxillofac Surg 2012; 2: 86-89.

10. Yildirim-Oz G, Tosun G, Kiziloglu D, Durmus E, Sener Y. An unusual association of odontomas with primary teeth. Eur J Dent 2007; 1: 45-49.

11. Hitchin AD. The aetiology of the calcified composite odontomes. Br Dent J 1971; 130: 475-482.

12. Ragalli CC, Ferreria JL, Blasco F. Large erupting complex odontoma. Int J Oral Maxillofac Surg 2000; 29: 373-374.

13. Perumal CJ, Mohamed A, Singh A, Noffke CE. Sequestrating giant complex odontoma: a case report and review of the literature. J Maxillofac Oral Surg 2013; 12: 480-484.

14. Phillips MD, Closmann JJ, Baus MR, Torske KR, Williams SB. Hybrid odontogenic tumor with features of ameloblastic fibro-odontoma, calcifying odontogenic cyst, and adenomatoid odontogenic tumor: a case report and review of the literature. J Oral Maxillofac Surg 2010; 68: 470-474.

15. Philipsen HP, Reichart PA, Praetorius F. Mixed odontogenic tumours and odontomas. Considerations on in terrelationship. Review of the literature and presentation of 134 new cases of odontomas. Oral Oncol 1997; 33: 8699.

16. Araki M, Kameoka S, Matsumoto N, Komiyama K. Usefulness of cone beam computed tomography for odontogenic myxoma. Dentomaxillofac Radiol 2007; 36: 423427.

17. Quereshy FA, Savell TA, Palomo JM. Applications of cone beam computed tomography in the practice of oral and maxillofacial surgery. J Oral Maxillofac Surg 2008; 66: 791-796.

18. Marques YM, Botelho TD, Xavier FC, Rangel AL, Rege IC, Mantesso A. Importance of cone beam computed tomography for diagnosis of calcifying cystic odontogenic tumour associated to odontoma. Report of a case. Med Oral Patol Oral Cir Bucal 2010; 15: e490-493. 
